\title{
Design of Geometric and Rigid Pavement Thickness on Jalan Lingkar Barat Sp. Sports Center - Bukit Sulap STA 0+100 - STA 7+583 Lubuklinggau City, South Sumatera Province
}

\author{
Kosim Kosim ${ }^{1 *}$, Julian Fikri ${ }^{1}$, Siswa Indra ${ }^{1}$, Kiky Rizky Amalia ${ }^{1}$, \\ Intan Puspita Sari², Yudha Prasetya ${ }^{2}$ \\ ${ }^{1}$ Lecturer of Teknik Sipil Politeknik Negeri Sriwijaya \\ ${ }^{2}$ Student of Prodi D-1V Perancangan Jalan dan Jembatan Politeknik Negeri Sriwijaya \\ *Corresponding author. Email: kosimmt@gmail.com
}

\begin{abstract}
Road construction is one of the government's efforts to facilitate the mobilization of the Indonesian people, both economically and socially. The purpose of this study was to design the geometric and rigid pavement thickness on Jalan Lingkar Barat SP Sports Center - Bukit Sulap STA 0+100 to STA 7+583 Lubuklinggau City, South Sumatra Province. The method used in this study was reviewing the vehicle volume, road terrain, and vehicle traffic load data. The analyses used were horizontal and vertical alignment calculations, and pavement thickness calculations. The generated design was referred to the standard criteria issued by the Indonesian Ministry of Public Works and Public Housing. The result from reviewing the vehicle volume, road terrain, and vehicle traffic load exhibited a total annual average daily traffic of $24404.06 \mathrm{SMP} /$ day. Therefore, this road has been classified as Jalan Arteri Kelas I. From the alignment calculation, the road was designed with 11 bends: 4 Spiral-Circle-Spiral (SCS) bends, 4 Full-Circle (FC) bends, and 3 Spiral-Spiral (SS) bends, with an average speed recommended in the plan was $70 \mathrm{~km} / \mathrm{h}$. As from the pavement thickness calculation, the pavement designed was the rigid pavement with a thickness of $19 \mathrm{~cm}$ and a bottom layer of sand gravel mixture with a thickness of $15 \mathrm{~cm}$
\end{abstract}

Keywords: Road, Geometric Design, Rigid Pavement Thickness

\section{INTRODUCTION}

Roads have become a fundamental piece of human life due to their role in facilitating the distribution of goods and services, connecting one region to another, and improving the economy and living standards. In other words, adequate road infrastructure such as determine the road condition and develop the roads based on standard planning could be a booster of economic development.

To gain the best result and the most efficient way to develop a new road or enhance the capacity of an existing road, the government needs some effective method in the designing process, includes determining the road's geometric design. Some of the main things in a geometric design include sufficient road width, the number of bends made based on the road's geometric technical requirements (both vertical and horizontal alignment), and pavement thickness. All these factors are needed for vehicles with particular load and speed to pass through it safely and comfortably.

Lubuklinggau City is located on the highway between Palembang City and Bengkulu City. Therefore, this city is also known as an economic liaison between Bengkulu Province and South Sumatra Province. The growth of the economic activity in Lubuklinggau City and its surroundings induce the escalate of the need for good quality infrastructures and facilities development in this city. Hence, the government of Lubuklinggau City constructs some new roads such as the Jalan Lingkar Barat

The Jalan Lingkar Barat is planned to be built from Petanang Village to Jogo Boyo Village, Lubuklinggau 
City (STA $0+100$ to STA 7+583). The government believes this construction is the best alternative to reduce the traffic load on the Sumateran Highway that is full of private vehicles, public transportations, and cargo. Besides, the government also has a vision to evenly distribute the economic development of the people in Lubuklinggau, improving their living standards. Therefore, this construction is an agenda to complete the development of the south, north, and west area of Lubuklinggau City.

This study aims to assist the construction of Jalan Lingkar Barat. Specifically, the purposes of this study are: (1) to generated the geometric design of Jalan Lingkar Barat; and (2) to generated the design of rigid pavement thickness of Jalan Lingkar Barat.

\section{RESEARCH METHOD}

To generate the design of geometric and rigid pavement thickness on Jalan Lingkar Barat Sp. Sports Center- Bukit Sulap, the researchers collected some technical data. Furthermore, the researchers calculated the horizontal and vertical alignment to produce a road alignment design, the type, and the number of bends needed. Parallelly, the researchers conducted the calculation of the recommended rigid pavement thickness as well. The technical data referred include topographic maps, average daily traffic, subgrade CBR, rainfall data, and the cost per unit of works, tools, and materials for the road construction.

This study used four structural standards applicable in Indonesia as the references, namely (1) Cement Concrete Pavement Planning (Pd T-14-2003) from Bina Marga; (2) Geometric Design Procedures for Inter-City Roads issued by the Directorate General of Highways in 1997; (3) The 2017 Road Pavement Design Manual issued by the Ministry of Public Works and Housing of the Republic of Indonesia; and (4) The 2003 Cement
Development Research Center of Department of Regional Infrastructure.

The flowchart in Figure 1 shows the process of pavement design generated from the collected data.

\section{FINDINGS}

\subsection{Geometric Design}

\subsubsection{Technical Data of the Road Design}
a. Type of terrain : Hiils
b. Average rainfall : $306,77 \mathrm{~mm} /$ year
c. Pavement design age : 20 years
d. Velometer design : $70 \mathrm{~km} /$ hour

For The 2020 traffic load, the data is shown on Table 1 below.

Table 1. The 2020 traffic load data of Jalan Jalan Lingkar Barat Sp. Sport Center - Bukit Sulap

\begin{tabular}{rlcc}
\hline No. & Vehicle Type & Characteristic & Total \\
\hline 1 & Type 1 & MC & 3235 \\
2 & Type 2 & LV & 953 \\
3 & Type 3 & LV & 1431 \\
4 & Type 4 & LV & 1116 \\
5 & Type 5A & LB & 412 \\
6 & Type 5B & LB & 154 \\
7 & Type 6A & MHV & 781 \\
8 & Type 6B & MHV & 488 \\
9 & Type 7A & LT & 63 \\
10 & Type 7B & LT & 1 \\
11 & Type 7C & LT & 67 \\
& & Total & 8701 \\
\hline
\end{tabular}

\subsubsection{Road Classification}

The traffic load data shown in Table 1 above is used

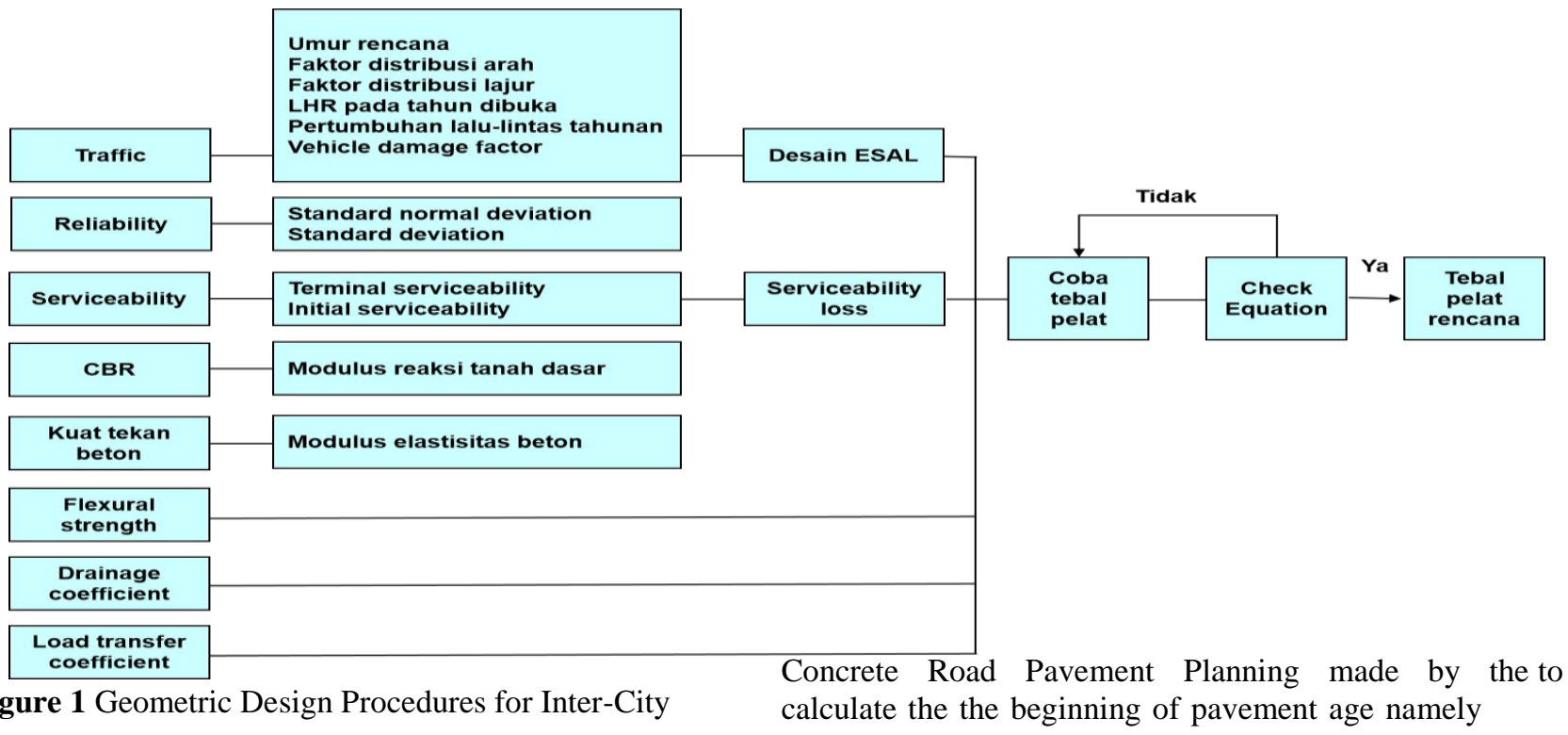


2021 annual average daily traffic (Lalu Lintas Harian Rata-rata or LHR). Using $\mathrm{n}=1$ and the traffic growth rate (i) based on the June 2017 revision of the SNI manual for pavement design $=4.83 \%$, the following equation is obtained.

$$
\operatorname{LHR}_{2021}=\operatorname{LHR} \times(1+\mathrm{i})^{\mathrm{n}}
$$

The results of the 2021 LHR calculation using Equations (1) are presented in Table 2 below.

Table 2 Calculated Data of 2021 LHR on Jalan Lingkar Barat Sp. Sports Center - Bukit Sulap

\begin{tabular}{cccc}
\hline No. Vehicle Type Total emp LHR (SMP) \\
\hline 1 Type 2 & 953 & 1,00 & 953 \\
2 Type 3 & 1431 & 1,00 & 1431 \\
3 Type 4 & 1116 & 1,00 & 1116 \\
4 Type 5A & 412 & 2,17 & 894,04 \\
5 Type 5B & 154 & 1,81 & 278,74 \\
6 Type 6A & 781 & 2,28 & 1780,68 \\
7 Type 6B & 488 & 1,80 & 878,40 \\
8 Type 7A & 63 & 2,11 & 132,93 \\
9 Type 7B & 1 & 1,80 & 1,80 \\
10 Type 7C & 67 & 2,13 & 142,71 \\
& TOTAL & & 7609,30 \\
\hline
\end{tabular}

The traffic growth rate in the beginning design is $4.83 \%$ and 20 years after it is opened (the pavement age design), it is assumed to be $6 \%$. From this assumption, the LHR data obtained in 2021 is $7979.83 \mathrm{SMP} /$ day and become 24404.06 SMP/day in 2041.

Based on the Geometric Design Procedures for Inter-City Roads No. 8/TBM/1997, Jalan Lingkar Barat Sp. Sports Center - Bukit Magic City Lubuk Linggau that has LHR > $20000 \mathrm{SMP} /$ day is classified as Jalan Arteri Kelas I. From the road classification and LHR obtained, the generated design of the road's width is $7 \mathrm{~m}$ with a shoulder width of $2 \mathrm{~m}$ on the left and right lanes.

\subsubsection{The Horizontal Alignment Calculation}

Based on topographic data and local road conditions, we generated 13 as shown in Table 3.

Table 3 Generated Coordinate Points

\begin{tabular}{ccc}
\hline Point & $\mathbf{X}$ & $\mathbf{Y}$ \\
\hline A & 9643200,948 & 260367,804 \\
P1 & 9642816,603 & 259895,517 \\
P2 & 9642509,189 & 259327,402 \\
P3 & 9642077,793 & 258943,394 \\
P4 & 9641760,718 & 258439,951 \\
P5 & 9641224,603 & 258277,047 \\
P6 & 9640699,584 & 258349,079 \\
P7 & 9640289,597 & 258805,136 \\
P8 & 9639824,891 & 259212,690 \\
P9 & 9639450,130 & 259755,551
\end{tabular}

\begin{tabular}{ccc}
\hline P10 & 9638825,933 & 260041,041 \\
P11 & 9638485,182 & 260661,072 \\
B & 9638315,522 & 261320,800 \\
\hline
\end{tabular}

From this data, the calculation of the road alignment shows the total road to be built is 7483.732 meters, with further data attached in Table 4 below.

Table 4 Calculation Results of Road Alignment and Azimuth

\begin{tabular}{cccc}
\hline No. & Alignment & Azimuth $\left({ }^{\circ}\right)$ & Length $(\mathbf{m})$ \\
\hline 1 & dA - P1 & 219,138 & 608,914 \\
2 & PI1 - PI2 & 208,418 & 645,955 \\
3 & PI2 - PI3 & 228,326 & 577,551 \\
4 & PI3 - PI4 & 212,203 & 594,971 \\
5 & PI4 - PI5 & 253,098 & 560,319 \\
6 & PI5 - PI6 & 277,812 & 529,937 \\
7 & PI6 - PI7 & 318,045 & 613,251 \\
8 & PI7 - PI8 & 311,251 & 618,104 \\
9 & PI8 - PI9 & 325,381 & 659,654 \\
10 & PI9-PI10 & 294,578 & 686,386 \\
11 & PI10-PI11 & 331,208 & 707,495 \\
12 & PI11-B & 345,578 & 681,194 \\
& Total & & 7483,732 \\
\hline
\end{tabular}

Forward, the calculation is carried out to find the bend's type as shown in the Table 5 below.

Table 5 Type of Bend

\begin{tabular}{ccc}
\hline Point & Bearing & Classification \\
\hline PI.1 & $10,720^{\circ}$ & Full-Circle \\
PI.2 & $19,908^{\circ}$ & Spiral-Circle-Spiral \\
PI.3 & $16,123^{\circ}$ & Spiral-Circle-Spiral \\
PI.4 & $40,895^{\circ}$ & Spiral-Spiral \\
PI.5 & $24,714^{\circ}$ & Spiral-Circle-Spiral \\
PI.6 & $40,233^{\circ}$ & Spiral-Spiral \\
PI.7 & $6,794^{\circ}$ & Full-Circle \\
PI.8 & $14,130^{\circ}$ & Full-Circle \\
PI.9 & $30,803^{\circ}$ & Spiral-Circle-Spiral \\
PI.10 & $36,630^{\circ}$ & Spiral-Spiral \\
PI.11 & $14,370^{\circ}$ & Full-Circle \\
\hline
\end{tabular}

The calculation results shows 11 bends, namely FullCircle bends (four), Spiral-Circle-Spiral bends (four) and Spiral-Spiral bends (three).

The sample calculation result of each type of bend and its superelevated are shown in the Figure 2, Figure 3, Figure 4,Figure 5, Figure 6, and Figure 7. 


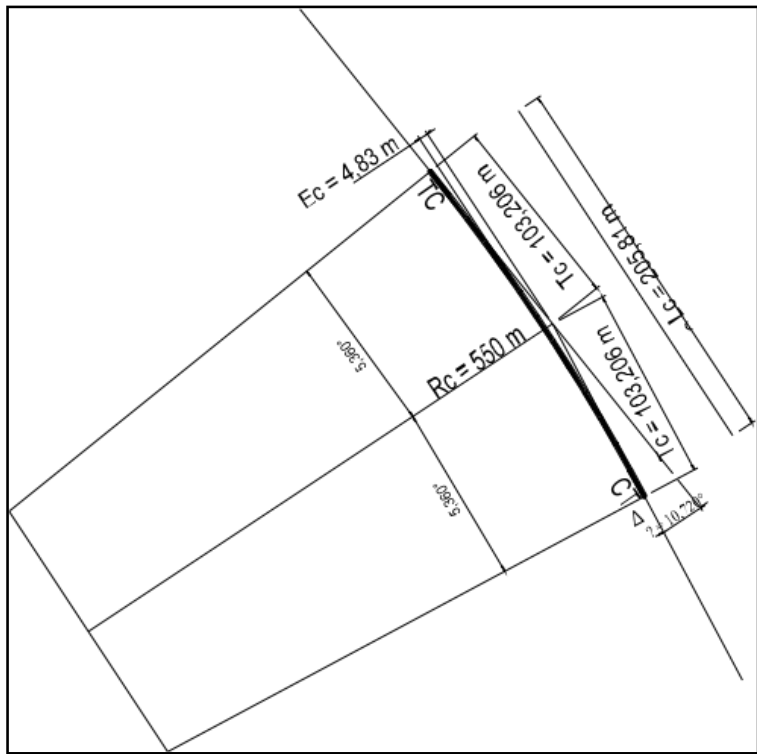

Figure 2 Full-Circle Bend Number 1

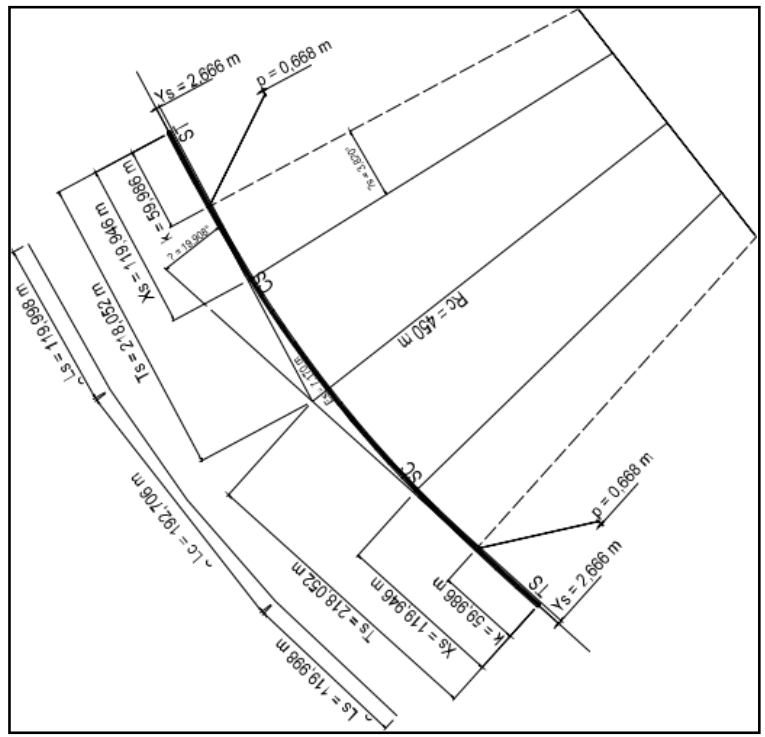

Figure 3 Spiral-Circle-Spiral Bend Number 2

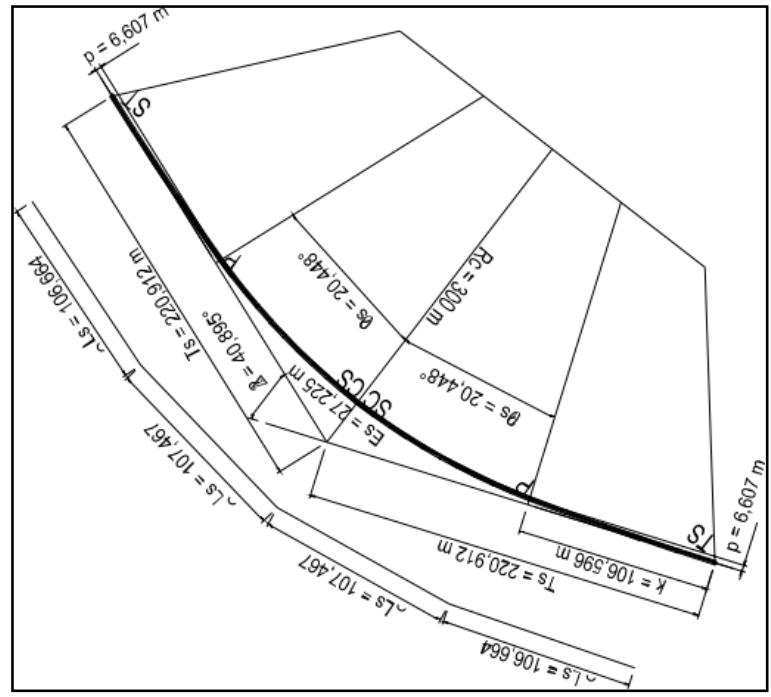

Figure 4 Spiral-Spiral Bend Number 4

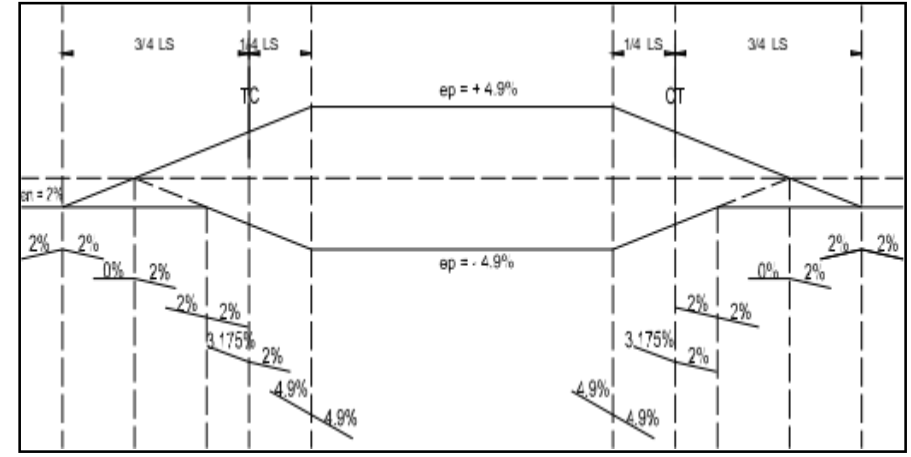

Figure 5 Superelevated Diagram of Full-Circle Bend Number 1

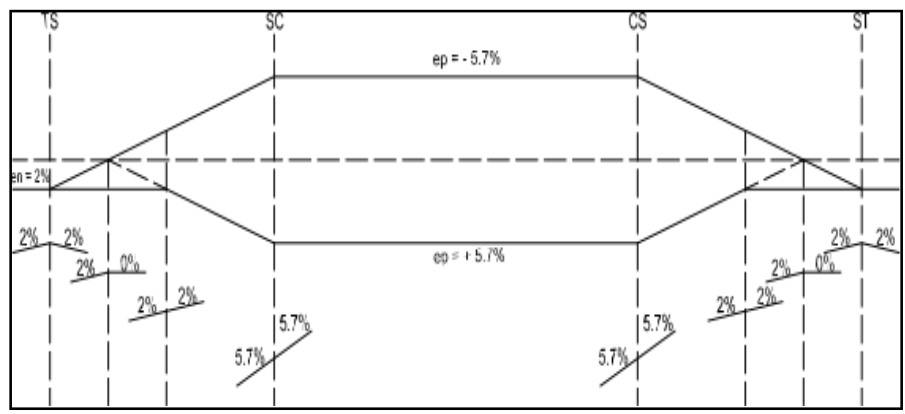

Figure 6 Superelevated Diagram of Spiral-Circle-Spiral Bend Number 2

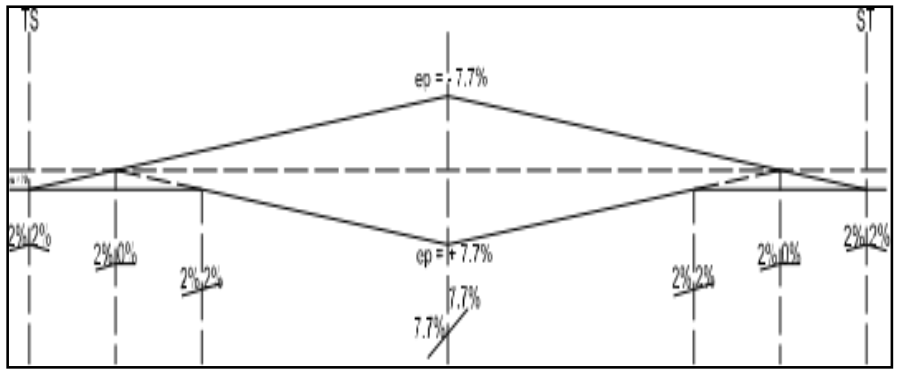

Figure 7 Superelevated Diagram of Spiral-Spiral Bend Number 4

\subsubsection{The Vertical Alignment Calculation}

From the vertical alignment calculation, the writers design a total of eight curves. Five of them are convex curves and the other three are concave curves. The vertical alignment calculation includes (1) slope design, (2) curve length, (3) curve stationing, and (4) vertical elevation.

\subsubsection{Convex Vertical Curve}

The Figure 8 below shows the sample of the road convex vertical curve.

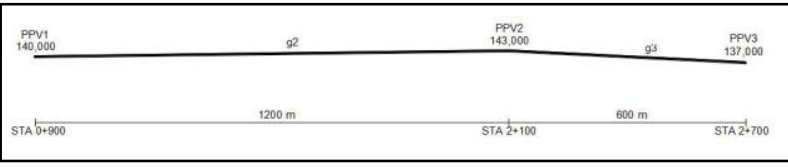

Figure 8 Convex Vertical Curve 
a) Slope Design (A)

The slope design is $1.25 \%$. It is calculated using the Equation 2.

$$
\mathrm{A}=|\mathrm{g} 3-\mathrm{g} 2|
$$

b) Curve Stationing

The Figure 9 shows the stationing of the curve.

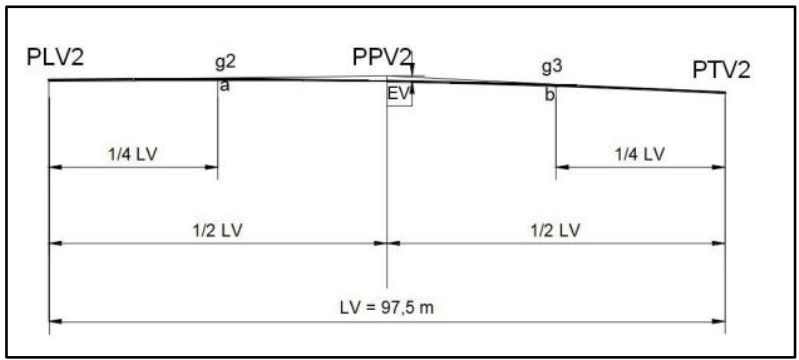

Figure 9 Convex Vertical Curve Calculation

Based on the Figure 9 above, we calculate the length of each station. Table 6 shows us how to calculate the length of each station that is used to define the vertical curve length and vertical elevation in the next sections.

Table 6 Stationing of Convex Vertical Curve

\begin{tabular}{lll}
\hline \multicolumn{1}{c}{ Station (STA) } & \multicolumn{1}{c}{ Calculation } & \multicolumn{1}{c}{ Length } \\
\hline PLV2 & STA PPV2 $-1 / 2 \mathrm{LV}$ & $2+051,250$ \\
$\mathrm{a}$ & STA PPV2 $-\mathrm{x}$ & $2+075,625$ \\
PPV2 & STA PPV2 & $2+100$ \\
$\mathrm{~b}$ & STA PPV2 $+\mathrm{x}$ & $2+124,375$ \\
PTV2 & STA PPV2 $+1 / 2 \mathrm{LV}$ & $2+148,750$ \\
\hline
\end{tabular}

c) Vertical Curve Length (Lv)

To find the right vertical curve length, we consider some requirement such as the shape flexibility, drainage and driver's comfort. The maximum Lv we got from those three requirement is 50 meters. To check the minimum length, the equation below shows the detail.

$$
\begin{aligned}
& \mathrm{Lv}=\frac{\mathrm{Jh}^{2}}{405}=\frac{97.5^{2}}{405}=23.472 \mathrm{~m}, 97.5 \mathrm{~m}(\mathrm{OK}) \\
& \mathrm{Ev}=\frac{\mathrm{Ax} \mathrm{Lv}}{800}=\frac{1.25 \times 97.5}{800}=0.152 \mathrm{~m} \\
& \mathrm{X}={ }^{1} \mathrm{~L} \mathrm{Lv}={ }_{4} 97.5=24.375 \mathrm{~m} \\
& \mathrm{Y}=\frac{\mathrm{AX}^{2}}{200 \mathrm{~L}}=\frac{1.25 \times 24.375^{2}}{200 \times 97.5}=0.038 \mathrm{~m}
\end{aligned}
$$

d) Vertical Elevation

The calculation of vertical elevation is summarize in Table 7 below.

Table 7 Vertical Elevation

\begin{tabular}{lcc}
\hline $\begin{array}{c}\text { Station } \\
\text { (STA) }\end{array}$ & Calculation & Elevation (m) \\
\hline PLV2 & Elev PPV2 $-\frac{1 / 2 L V \times g^{2}}{100}$ & 142.878 \\
a & Elev PPV2 $-\frac{1 / 4 L V \times g^{2}}{100-\mathrm{y}}$ & 142.901 \\
PPV2 & Elev PPV2 $-\mathrm{Ev}$ & 142.848 \\
$\mathrm{~b}$ & Elev PPV2 $-\frac{1 / 4 L V \times g^{3}}{100-\mathrm{y}}$ & 142.718 \\
PTV2 & Elev PPV2 $-\frac{1 / 2 L v \times g^{3}}{100}$ & 142.513 \\
\hline
\end{tabular}

\subsubsection{Concave Vertical Curve}

The Figure 8 below shows the sample of the road convex vertical curve.

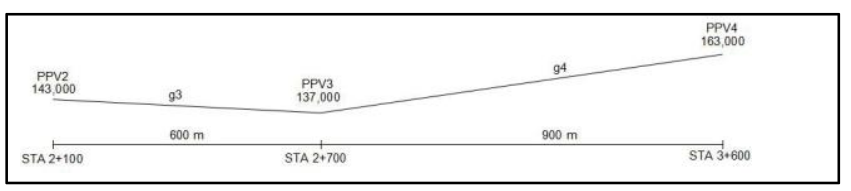

Figure 10 Concave Vertical Curve

a) Slope Design (A)

The slope design is $3.899 \%$. It is calculated using the Equation 3.

$$
\mathrm{A}=|\mathrm{g} 4-\mathrm{g} 3|
$$

b) Curve Stationing

The Figure 11 shows the stationing of the curve.

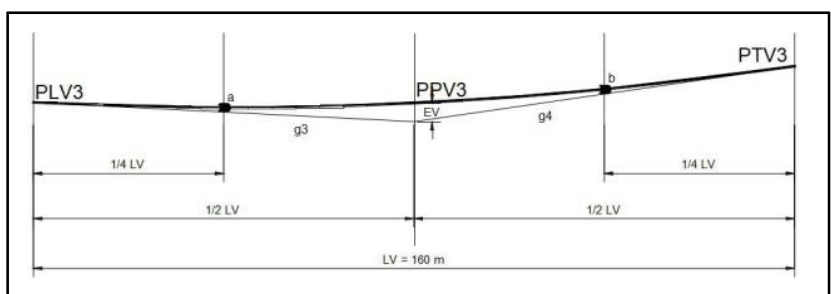

Figure 11 Concave Vertical Curve Calculation

Based on the Figure 11 above, we calculate the length of each station. Table 8 shows us how to calculate the length of each station that is used to define the vertical curve length and vertical elevation in the next sections. 
Table 8 Stationing of Concave Vertical Curve

\begin{tabular}{llc}
\hline \multicolumn{1}{c}{ Station (STA) } & \multicolumn{1}{c}{ Calculation } & Length \\
\hline PLV3 & STA PPV3 - 1/2 LV & $2+620$ \\
a & STA PPV3 - x & $2+660$ \\
PPV3 & STA PPV3 & $2+700$ \\
b & STA PPV3 + x & $2+740$ \\
PTV3 & STA PPV3 + 1/2 LV & $2+780$ \\
\hline
\end{tabular}

c) Vertical Curve Length (Lv)

To find the right vertical curve length, we consider

some requirement such as the shape flexibility, drainage and driver's comfort. The maximum Lv we got from

those three requirement is 160 meters. To check the minimum length, the equation below shows the detail.

$\mathrm{Lv}=\frac{\mathrm{Jh} 2}{405}=\frac{97.52}{405}=23.472 \mathrm{~m}, 97.5 \mathrm{~m}(\mathrm{OK})$

$\mathrm{Ev}=\frac{\mathrm{Ax} \mathrm{LV}}{800}=\frac{3.899 \times 160}{800}=0.152 \mathrm{~m}$

$\mathrm{X}={ }^{1}{ }_{4} \mathrm{Lv}={ }_{4} \mathrm{~K} 60=40 \mathrm{~m}$

$\mathrm{Y}=\frac{\mathrm{AX}^{2}}{200 \mathrm{~L}}=\frac{3.899 \times 40^{2}}{200160}=0.195 \mathrm{~m}$ d) Vertical Elevation

The calculation of vertical elevation is summarize in Table 9 below.

Table 9 Vertical Elevation

\begin{tabular}{|c|c|c|}
\hline $\begin{array}{l}\text { Station } \\
\text { (STA) }\end{array}$ & Calculation & Elevation (m) \\
\hline PLV3 & Elev PPV3 $+\frac{1 / 2 L v \times g^{3}}{100}$ & 137.800 \\
\hline $\mathrm{a}$ & Elev PPV3 $+\frac{1 / 4 L v \times g^{3}}{100+y}$ & 137.595 \\
\hline PPV2 & Elev PPV3 + Ev & 137.780 \\
\hline b & Elev PPV3 $+\frac{1 / L v \times g^{4}}{100+y}$ & 138.355 \\
\hline PTV3 & Elev PPV3 $+\frac{\ngtr_{2} L v \times g^{4}}{100}$ & 139.319 \\
\hline
\end{tabular}

\subsection{Calculation of Concrete Slab Thickness in Rigid Pavement Design}

Type of work : Connected Concrete with Reinforcement Type of shoulder : Sand-gravel mixture

Pavement age design : 20 years

JSKN design $\quad: 3,78 \times 10^{7}$

Safety factor $\quad: 1,1$

Concrete flexural strength : 4,0 Mpa

Foundation layer : Sand-gravel mixture layer

Foundation layer thickness: $15 \mathrm{~cm}$

CBR : $4,9 \%$

Effective CBR : $33 \%$

Table $1019 \mathrm{~cm}$ of Slab Thickness Calculation

\begin{tabular}{|c|c|c|c|c|c|c|c|c|}
\hline \multirow[b]{2}{*}{ Axis } & \multirow{2}{*}{$\begin{array}{l}\text { Design load } \\
\text { of each axle } \\
\text { ton (Kn) }\end{array}$} & \multirow{2}{*}{$\begin{array}{l}\text { Design load } \\
\text { of each } \\
\text { wheel }\end{array}$} & \multirow[b]{2}{*}{ Repition } & \multirow{2}{*}{$\begin{array}{c}\text { Tension } \\
\text { Factor and } \\
\text { Erotion }\end{array}$} & \multicolumn{2}{|c|}{ Fatigue Analisys } & \multicolumn{2}{|c|}{ Erotion Analysis } \\
\hline & & & & & Repition & $\begin{array}{c}\text { Damage } \\
\text { Percentage }(\%)\end{array}$ & Repition & $\begin{array}{c}\text { Damage } \\
\text { Percentage }(\%) \\
\end{array}$ \\
\hline 1 & 2 & 3 & 4 & 5 & 6 & $7=4 * 100 / 6$ & 8 & $9=4 * 100 / 8$ \\
\hline \multirow{6}{*}{ STRT } & $6(60)$ & 33 & 1217256,637 & & TT & 0 & TT & 0 \\
\hline & $5(50)$ & 27,5 & 5798230,088 & $\mathrm{TE}=1,03$ & $\mathrm{TT}$ & 0 & $\mathrm{TT}$ & 0 \\
\hline & $4(40)$ & 22 & $7257079,646 \mathrm{I}$ & $\mathrm{FRT}=0,258$ & $\mathrm{TT}$ & 0 & TT & 0 \\
\hline & $3(30)$ & 16,5 & 5259292,035 & $\mathrm{FE}=2,26$ & TT & 0 & $\mathrm{TT}$ & 0 \\
\hline & $2(20)$ & 11 & 7257079,646 & & $\mathrm{TT}$ & 0 & & \\
\hline & $8(80)$ & 22 & 4534513,274 & $\mathrm{TE}=1,63$ & TT & 0 & TT & 0 \\
\hline STRG & $5(50)$ & 13,75 & $5259292,035 \mathrm{I}$ & $\mathrm{FRT}=0,408$ & TT & 0 & $\mathrm{TT}$ & 0 \\
\hline \multirow[t]{2}{*}{ STdRG } & $14(140)$ & 19,25 & 1217256,637 & $\begin{aligned} \mathrm{FE} & =2,87 \\
\mathrm{TE} & =1,33 \\
\mathrm{FRT} & =0,333 \\
\mathrm{FE} & =2,95\end{aligned}$ & TT & 0 & TT & 0 \\
\hline & & otal & & & & $\%<100 \%$ & & $b<100 \%$ \\
\hline
\end{tabular}


Figure 12 below shows the transverse shrinkage joint using Dowel on connected concrete pavement without reinformed and the reinforment of connected concrete pavement with reinforced.

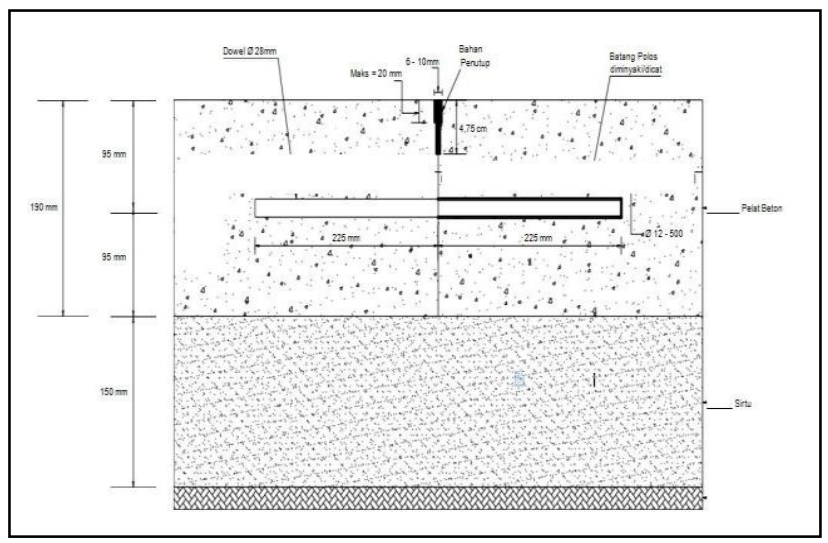

Figure 12 transverse shrinkage joint using Dowel on connected concrete pavement without reinformed

\section{CONCLUSION}

(1) The result from reviewing the vehicle volume, road terrain, and vehicle traffic load exhibites a total annual average daily traffic of 24404.06 SMP/day. Therefore, this road has been classified as Jalan Arteri Kelas I.

(2) From the alignment calculation, the road is designed with 11 bends: 4 Spiral-Circle-Spiral (SCS) bends, 4 Full-Circle (FC) bends, and 3 Spiral-Spiral (SS) bends with 8 vertical curve (5 convex curve and 3 concave curve).

(3) The average speed recommended in the plan is 70 $\mathrm{km} / \mathrm{h}$.

(4) From the pavement thickness calculation, the pavement designed is the rigid pavement with a thickness of $19 \mathrm{~cm}$ and a bottom layer of sandgravel mixture with a thickness of $15 \mathrm{~cm}$.

\section{ACKNOWLEDGMENTS}

We thanks to Politeknik Sriwijaya for the opportunity to conduct this study.

\section{REFERENCES}

[1] Departemen Pekerjaan Umum, 2016. Analisa Harga Satuan Pekerjaan (AHSP) Bidang Pekerjaan Umum. Jakarta: Kementerian Pekerjaan Umum dan Perumahan Rakya

[2] Direktorat Jenderal Bina Marga, 2017. Manual Desain Perkerasan Jalan. Jakarta: Kementerian Pekerjaan Umum RI

[3] Direktorat Jenderal Bina Marga, 1997. Manual Kapasitas Jalan Indonesia. Jakarta: Kementerian Pekerjaan Umum RI.
[4] Departemen Pekerjaan Umum, 2006. Pedoman Sistem Drainase Jalan Pd T-02-2006-B, Direktorat Bina Teknik, Jakarta.

[5] Departemen Pekerjaan Umum, Direktorat Jenderal Bina Marga, 1997, Tata Cara Perencanaan Geometrik Jalan Antar Kota, Jakarta

[6] Departemen Pemukiman dan Prasarana Wilayah, Pusat Penelitian Pengembaangan Jalan, 2003, Perencaan Perkerasan Jalan Beton Semen, Jakarta.

[7] Departemen Pekerjaan Umum, Direktorat Jenderal Bina Marga, 1987, Standar Gorong-Gorong Persegi BetonBertulang (Box Culvert) Tipe Single.

[8] Hendarsin, S.L., 2000. Perencanaan Teknik Jalan Raya. Politeknik Negeri Bandung: Bandung.

[9] Sukirman, Silvia, 1999. Dasar-Dasar Perencanaan Geometrik Jalan. Nova: Bandung. 